\title{
WÉBER ANTAL KÖNYVTÁRA
}

\author{
ADALÉK A XIX. SZÁZADI MAGYAR ÉPÍTÉSZETI SZAKIRODALOM \\ KUTATÁSÁHOZ
}

\author{
MARÓTZY KATALIN*
}

\begin{abstract}
A XIX. században jelentősen megnőtt a kiadott építészeti témájú könyvek száma, köszönhetően a sokszorosítási - metszési, litográf - technikák fejlődésének is. A korábbiakhoz képest gyorsabb tájékoztatást jelentettek az építészek számára Magyarországon a havonta megjelenő építészeti szakfolyóiratok, a magyar nyelvü Épitési Ipar és a német nyelvű Budapester Bauzeitung. Ezek az építészeti könyvek és folyóiratok nagyrészt szerepelnek könyvtáraink állományában, azonban nehéz megítélni, hogy az egyes építész műveltsége milyen széles körű lehetett, ha nem ismerjük a nagy mesterek személyes könyvtárait. A Budapesti Műszaki és Gazdaságtudományi Egyetem Központi Könyvtárában szerencsésen megmaradt Wéber Antal könyvtára, ennek áttekintésével közelebb kerülhetünk a XIX. századi építészeti szakirodalom mélyebb megismeréséhez.
\end{abstract}

Kulcsszavak: építészettörténet, historizmus, építészeti szakirodalom

A magyarországi építészeti szakirodalmat a XVIII. századig visszamenően kutatták építész- és múvészettörténészek, a korai időszakot Bibó István dolgozta fel, részletes tanulmányában ${ }^{1}$ tematikusan is tárgyalva a különböző típusú könyveket. A közelmúltban publikálták a dégi Festetics-kastély könyvtárának építészettel

* egyetemi tanársegéd, Budapesti Műszaki és Gazdaságtudományi Egyetem Építészettörténeti és Múemléki Tanszék. 1111 Budapest Múegyetem rkp. 3. K. II. 60. Tel.: 463-1330, fax: 463-1638.

1 Bibó István: A magyar építészeti szakirodalom kezdetei (Építészeti szakkönyvek Magyarországon a XVIII. században). In: Müvészet és felvilágosodás. Szerk.: Zádor Anna, Szabolcsi Hedvig. Akadémiai Kiadó, Budapest, 1978. pp. 27-123. 
foglalkozó, elsősorban XVIII. századi munkákat tartalmazó jegyzékét. ${ }^{2}$ Ismertté vált Andreas Miller - a körmendi Batthyány-kastély építési írnokának - negyvennégy építészeti témájú könyvet is tartalmazó könyvtárának jegyzéke is 1733-ból, amivel az egyes építész múveltségének megismeréséhez jutottunk közelebb. ${ }^{3}$

A XIX. században megnőtt a kiadott építészeti könyvek száma, a különböző metszési és litográf technikák fejlődésével olcsóbbá vált a nyomtatás, a század közepétől egyre több külföldi kiadó foglalkozott szakkönyvek kiadásával. A korábbiakhoz képest gyorsabb tájékoztatást jelentettek az építészek számára a Magyarországon megjelenő építészeti szakfolyóiratok, a magyar nyelvü Épitési Ipar - később Épitö Ipar, majd Épitö Müvészet - és a német nyelvü Budapester Bauzeitung - később Bauzeitung für Ungarn címen. Rendszeresen közölt építészeti témájú tanulmányokat az 1867-től évenként kiadott Magyar Mérnök-Egylet Közlönye - később Magyar Mérnök- és Épitészegylet Közlönye - is.

A XIX. században megjelent építészeti könyvek és folyóiratok nagy része szerepel könyvtáraink állományában. ${ }^{4}$ A könyveket lapozva alkalmanként ismert XIX. századi építészek ex-libriseivel is találkozhatunk, azonban nehéz megítélni, hogy az egyes építész múveltsége milyen széles körü lehetett, ha nem ismerjük a nagy mesterek teljes könyvtárait. A Budapesti Múszaki és Gazdaságtudományi Egyetem Központi Könyvtárának állományában szerencsésen megmaradt Wéber Antal rendkívül gazdag könyvtárának egy része, ${ }^{5}$ ennek áttekintésével közelebb kerülhetünk a XIX. századi építészeti szakirodalom mélyebb megismeréséhez. Külön jelentőséget ad a témának, hogy a századból mind ez idáig nem kerültek elő magánépítészek könyvtárainak jegyzékei.

Wéber Antal (1823-1889) ${ }^{6}$ a kiegyezés utáni Budapest jelentős építésze volt. A korabeli rend szerint képzése a céhes rendszeren belül kezdődött, majd ismereteit Bécsben gyarapította. Építészi pályafutása a szabadságharcban vállalt szerepe miatti kényszerủ szünet után kezdődhetett. Néhány fơúri megbízásból készült, vidéki romantikus kastély után elsősorban Budapesten alkotott neoreneszánsz stílusú bérházakat, bérpalotákat és villákat. 1881-től a Vallás- és Közoktatásügyi Minisztérium építészeként vidéki és fóvárosi oktatási épületeket tervezett.

2 Sisa József: A dégi Festetics-kastély. Múemlékek Állami Gondnoksága, Budapest, 2005. p. 126.

Koppány Tibor: Andreas Miller körmendi Bauschreiber könyvtárának jegyzéke 1733-ból. In: Romantikus kastély - Tanulmányok Komárik Dénes tiszteletére. Hild-Ybl Alapítvány, Budapest, 2005. pp. 67-73.

4 Elsősorban azokon a helyeken, amelyek intézményi elődjében már a XIX. században is folyt múvészeti vagy építészeti oktatás.

5 Jegyzéke a cikk végén. A 101 tételes listából mindössze négy „lappang” és egyet töröltek az állományból (leltári szám szerint: 6548., 6557., 6570., 6582., 6586.).

6 Életrajzát részletesen közölte Ybl Ervin. (Ybl Ervin: Weber Antal. Épités-és Közlekedéstudományi Közlemények 1958. Nr. 3-4. pp. 417-442.) 


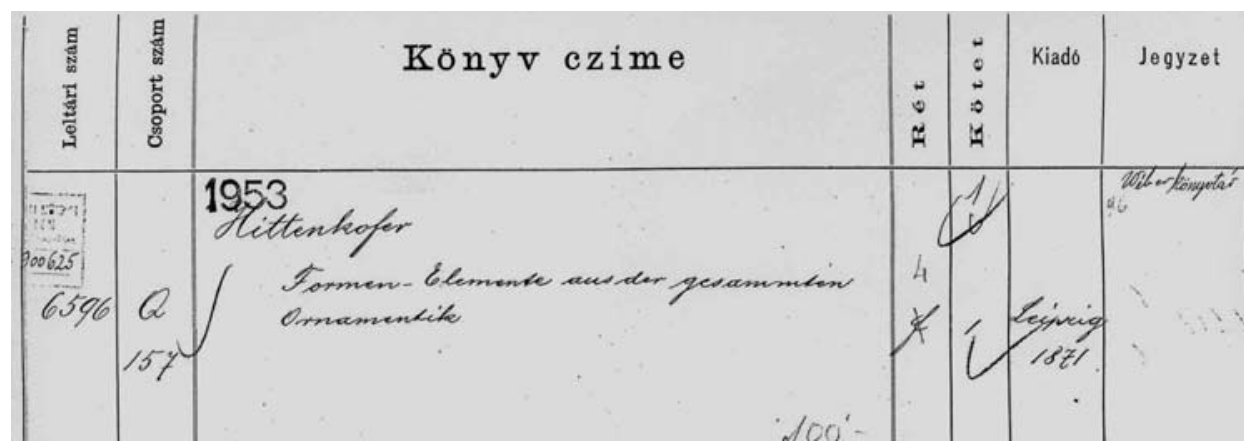

1. ábra. A Müegyetemi Könyvtár leltárkönyének egyik sora

Wéber Antal építész könyveit Trefort Ágoston kultuszminiszter Szily Kálmán rektor, Hauszmann Alajos, Steindl Imre és Wartha Vince professzorok javaslatára vásárolta meg a Királyi József Múegyetem könyvtára számára 1880-ban, 6440 forintért. $^{7}$ Az összeg felét az államkincstár, felét a múegyetemi tanári testület fedezte. Az építészi szakosztálynak nagy szüksége lehetett korszerü könyvekre, a Királyi József Műegyetem könyvtárában addig mindössze 22 műépítészeti témájú könyvet lehetett találni, ${ }^{8}$ melyek között például nem volt olyan, mely a reneszánsz

7 Az éves költségvetés indoklásában Trefort Ágoston a következőképpen fogalmazott: „A könyvtárnak, különösen az épitési és müépitési szakban kiegészitésre kedvezö alkalom nyilt Weber Antal müépitész 278 folio kötetet és 21.394 lap rajzot tartalmazó szakkönyvtárának eladóvá tételével, mely a bemutatott lajstromok szerint 10.000 frtnál jóval többe került s becsére azon könyvek leszámításával is, melyek a müegyetem könyvtárában már megvannak, felülmulja a 8.000 frtot. A könyvtár valóban becses és épen a müegyetemnek való volta s a mellett jutányossága kétségen kivül lévén, annyival kevésbé lehetett, e jó alkalmat elszalasztani, mert ezzel a müegyetem szertáraira pár év múlván ugyis teendö tetemesb kiadások egy része most már fedeztetvén, e kiadás csak az akkori nagyobb kiadást fogja könnyebiteni."

A Vallás- és közoktatásügyi ministerium 1881. évi költségvetésének indoklása. Budapest, 1880. (Magyar Országos Levéltár K 802/94. kötet, Vallás és Közoktatásügyi Minisztérium Elnöki iratok). Összehasonlításképpen a II. számú úgynevezett Wágner-féle klinika múvezetési díja ugyanebben az évben 6900 forint volt. (Ybl 1958. p. 432.)

8 Ezek a leltárkönyvek és A Magyar Királyi József Müegyetem Könyvtárának czímjegyzéke. 2. kiad. Budapest, 1893. szerint, a leltárbavétel sorrendjében:

E. Meztger: Sammlung griechischer Bau-Profile. München, 1839. 1846.

H. Weishaupt: Griechische und römische Verzierungen nach antiken Mustern. München,

C. A. Rosenthal: Vollständige Uebersicht der Geschichte der Baukunst. Berlin, 1841-50.

C. L. Stieglitz: Von altdeutscher Baukunst. Atlas. Leipzig, 1820.

K. Heideloff: Les ornements du moyen age. Nürnberg, 1852.

L. Puttrich: Denkmale der Baukunst des Mittelalters in Sachsen. Leipzig, 1835-50.

I. Gailhaud: Denkmäler der Baukunst. Hamburg, 1852.

C. F. A. Lützow: Die Meisterwerke der Kirchenbaukunst. Leipzig, 1862. 
építészetet részletesen tárgyalta volna. A könyvtár bővítése is hozzájárult a magyar egyetemi szintủ építészképzés korszerübbé tételéhez. Az 1880-as évek elején a tanszabadság eltörlésével, új építésztanárok alkalmazásával, új tanszékek létesítésével az elóző évtizedben még az alakulás nehézségeivel küzdő építész-szakosztály jelentős fejlődésnek indult. A historizáló kor igényeinek megfelelően a történeti formák minél alaposabb oktatását tüzték ki célul, ${ }^{9}$ és ehhez elengedhetetlen volt egy, a történeti építészetet átfogó könyvtári háttér.

Érdemes ezt a maga korában nagyra tartott állományt tematikusan áttekinteni. Az építészeti munkák között mindösszesen egy elméleti ${ }^{10}$ munka van, LéopoldCamille Cernesson múve, ${ }^{11}$ amely a geometriai szerkesztéseket és építészeti alkalmazásukat mutatja be. A Wéber Antaltól vásárolt könyvek között az építészetet átfogóan leíró vagy egy tervezési résztémát elméleti megközelítésben ismertető könyv nincsen.

Az anyag gerincét a különböző épitészettörténeti témájú müvek adják. Elsősorban az összefoglaló jellegü múvek alapján láthatjuk, hogy az építészet történeté-

G. Semper: Der Stil in den technischen und tektonischen Künsten oder praktische Aesthetik. Frankfurt, 1860-63.

Fr. Kugler: Handbuch der Kunstgeschichte. Stuttgart, 1861.

Fr. Kugler: Geschichte der Baukunst. Stuttgart, 1856-79.

W. Lübke: Geschichte der Architektur von den ältesten Zeiten bis auf die Gegenwart. Leipzig, 1865-70.

W. Lübke: Geschichte der Plastik von den ältesten Zeiten bis auf die Gegenwart. Leipzig, $1863-71$.

C. Köhler: Lehrbuch zum Studium der kirchlichen Kunst des deutschen Mittelalters. Leipzig, 1866.

W. Lübke: Kunsthistorische Studien. Stuttgart, 1869.

L. Gerlach: Illustriertes Wörterbuch der mittelälterlichen Kirchenbaukunst. Stuttgart, 1871.

Fr. Oesten: Die Bauwerke in der Lombardei vom 7-ten bis zum 14-ten Jahrhundert.

O. Jones: Grammatik der Ornamente. London, 1868.

H. A. Müller, O. Mothes: Illustriertes Archeologisches Wörterbuch. Leipzig, 1876-78.

J. J. Winkelmann: Geschichte der Kunst des Altertums. Berlin, 1870.

H. Schliemann: Mykenae. Bericht über meine Forschungen und Entdeckungen in Mykenae und Tiryns. Leipzig, 1878.

Steindl I.: Magyarországi müemlékek. Budapest, 1878.

9 Az 1887-es tanévet Kisfaludi Lipthay Sándor rektor a következő szavakkal nyitotta meg: (a szakosztály célkitűzéseiről) „,növendékei általános tájékozódást szerezhessenek minden stylirányban és hogy elsajátithassák a tervezésnek azt a sajátos jártasságát, amely biztos alapját képezi annak, hogy az életbe lépve magukat majdan bármely stylirányban tökéletesen feltalálhassák és kimüvelhessék." Szentkirályi Zoltán: Adatok a magyar építészképzés történetéhez. Épités- Épitészettudomány 1972. Nr. 3. pp. 450-453.

${ }^{10}$ A temetikus ismertetésnél Bibó István rendszerét követve és a könyvtár egyedi jellegzetességei szerint kiegészítve (Bibó 1978).

${ }^{11} 6670$. 
nek feldolgozása még a kezdeteknél tartott. Míg az egyes korszakok épületeit helyszíni felmérések és leírások alapján bemutató albumokat ma is megbízható forrásként használhatjuk, néhány áttekintő mű szemlélete vagy válogatási szempontja ${ }^{12}$ furcsának tünhet. Ma is széles körünek tekinthető összefoglalást ad Ernst Förster német építészetet bemutató könyve és Eugène Emmanuele Viollet-le-Duc építészettörténeti szakszótára. ${ }^{13}$

Korszakonként végigtekintve az anyagon, feltűnő az antik és a reneszánsz építészetet feldolgozó müvek túlsúlya. Nem lehet pontosan tudni, hogy Wéber könyvtárából az eladásra szánt köteteket maga válogatta ki, vagy esetleg a múegyetemi professzorok kérésének tett eleget. Valószínú, hogy Wéber személyes - a klasszikus és reneszánsz formákat nagyra tartó - ízlése, melyet megépült épületein is nyomon követhetünk, és az építésztanárok oktatáshoz kötődő igényei közel állhattak egymáshoz.

Az ókori témájú könyvek néhány felmérési rajzon túl elsősorban romantikus felfogású látképeket tartalmaznak, átfogják az akkor ismert klasszikus építészetet. A korszakot bemutató könyvek közül a legérdekesebb egy fotóalbum, amely a technika újdonságán túl azzal az élménnyel ajándékozta meg az olvasót, hogy a talán soha el nem érhető messziségben lévő - egyiptomi, Közel-Keleti - épületeket jó minőségü képeken keresztül tette élvezhetővé. ${ }^{14}$ A középkort csak egy francia, egy német és két olasz építészetet feldolgozó könyv képviseli az állományban. ${ }^{15}$ $\mathrm{Az}$ iszlám építészettel Léon Parvillée, Owen Jones, Friedrich Maximilian Hessemer munkái foglalkoznak. ${ }^{16}$

A reneszánsz korszakot bemutató múvek a részletképzésig terjedő alapossággal mutatják be a korszakot. Találunk egy-egy épület, ${ }^{17}$ egy-egy város ${ }^{18}$ építészetét bemutató és a korszakot nemzeti szempontból összefoglaló ${ }^{19}$ könyvet is. Wéber Antal könyvtárából elsősorban Itália és Franciaország reneszánsz építészete ismerhető meg mélyebben.

\footnotetext{
12 Bizonyos könyveknél feltételezhetjük, hogy a válogatás alapját nem tudományos kutatás, hanem a személyes úti élmények jelentették (6592., 6602.).

${ }^{13} 6569 ., 6542$.

14 A kor magyarországi építésze számára egy itáliai, német vagy francia út megfizethető volt, tanulmányaikat is sokan folytatták külföldön. Pár évtizeddel később például Hauszmann Alajos és Alpár Ignác már jóval messzebb utazhattak. A külföldi tanulmányutakkal részletesen foglalkozik Sisa József. (Sisa József: Magyar építészek külföldi tanulmányútjai a 19. század második felében. Müvészettörténeti Értesitö 1996. Nr. 3-4. pp. 169-186.)

${ }^{15}$ 6551., 6545., 6547., 6671.

16 6608., 6558., 6611.

${ }^{17}$ 6557., 6571., 6580., 6581., 6584., 6612.

18 6560., 6561 .

19 6539., 6583., 6585., 6603., 6607.
} 
A könyvtár legnagyobb részét kitevő történeti müveken felül jelentős számban szerepelnek a kortárs építészetet bemutató könyvek és albumok, ${ }^{20}$ melyek az építészeti publikációk múfajának máig élő típusait képviselik. Tematikus összefoglaló műnek nevezhetők Eugène Emmanuele Viollet-le-Duc és César Daly könyvei, előbbi a lakóház-építészettel, utóbbi a temetői építményekkel foglalkozik. ${ }^{21}$ Topografikus megközelítésúek a francia, német és bécsi építészetet bemutató munkák. ${ }^{22}$ Az egyes épületeket publikáló kötetek között találunk olyat, amely csak fényképeken keresztül mutatja be az elkészült múvet, ${ }^{23}$ és olyanokat is, melyek az épület teljes építéstörténetét a terveken kívül szövegesen is feldolgozzák. ${ }^{24}$ Karl Friedrich Schinkel építészetét két, meg nem épült athéni és krími tervének ${ }^{25}$ bemutatásán kívül építészeti terveinek gyüjteménye is képviseli. Az építészettörténészek számára rendkívül fontos mú érdekessége, hogy egy-egy épülethez több tervváltozatot is közöl, megvilágítva a kutató számára a historizáló tervezés jellegzetességeit. A XIX. század második felétől egyre inkább befolyásolja az építészet fejlődését a tervpályázatok eredménye is, ebben a könyvben a hamburgi városháza-pályázat díjazott terveinek publikációját találjuk. ${ }^{26}$

A teljes anyagban mindössze egy mintakönyvnek nevezhető kiadvány van. Hittenkofer gyakorló tanárként ${ }^{27}$ elsősorban a diákok és kezdő építészek számára jól használható művet adott közre. ${ }^{28} \mathrm{~A}$ - maga korában ritkaságnak számító - forrásmegjelöléssel is ellátott bevezető után az egyes formák „felhasználási helyük” szerinti csoportosításban szerepelnek.

Az épitészet témájához szorosan kapcsolódnak a belsőépítészettel, bútortörténettel foglalkozó könyvek, Eugène Emmanuele Viollet-le-Duc, Paul Vredeman de Vriese és Eugène Prignot összefoglaló jellegű és Valentin Teirich egyetlen bútordarabot bemutató műve. ${ }^{29}$ A kerttervezéssel Artur Mangin igényes szövegközi illusztrációkkal ellátott történeti felfogásban készült albuma foglalkozik. ${ }^{30}$ Az építészethez közvetettebben kapcsolódnak az iparmüvészeti és iparmúvészet-történeti

${ }^{20}$ A történeti témák 46, a kortárs építészet 26 tétellel.

${ }^{21}$ 6605., 6609.

22 Bécs: 6604., 6672., francia: 6538., 6595., 6619., német: 6597., 6618., 6538.

23 A három kötet a Charles Garnier által tervezett párizsi Opera elsősorban a társmúvészeti alkotásait mutatja be, legtöbbször beépítés előtti állapotban készült fényképeken. (6577., 6578., 6579.)

${ }^{24}$ 6554., 6598., 6610., 6554.

25 6572., 6573., 6574

${ }^{26}$ Az ötven táblán keresztül bemutatott tervekhez mellékelték a pályázat eredeti kiírását és a zsüri részletes véleményét tartalmazó füzetet. (6613.)

${ }^{27}$ Lehrer der Herzoglichen Braunschweigischen Baugewerkenschule zu Holzminden. (6596. belső borító.)

${ }^{28} 6596$

${ }^{29}$ 6541., 6590., 6582., 6699., 6601.

306555 . 


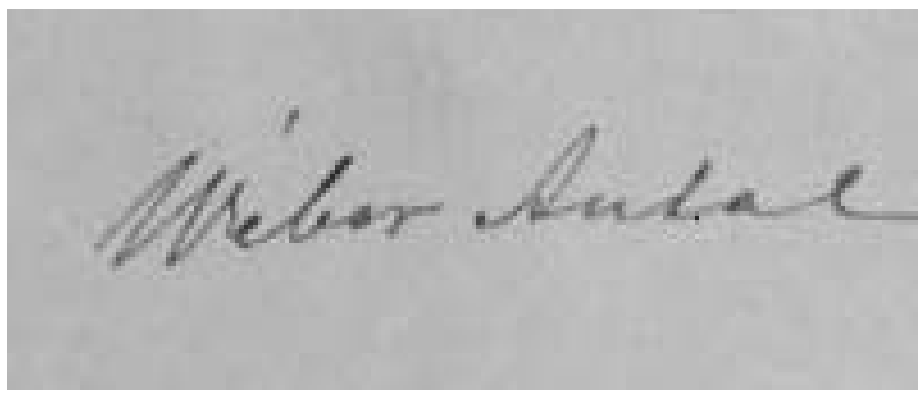

2. ábra. Wéber Antal szignója

művek, melyek - a keleti és délszláv szőttesektől az intarziákon át az öltözködéstörténetig - szerteágazó témákat ölelnek fel. ${ }^{31}$

A képzőművészeti témájú könyvek a tulajdonos klasszikus ízléséről tanúskodnak. Történeti témát dolgoznak fel Koch és Arosa múvei, ${ }^{32}$ előbbi hat antik reliefet, utóbbi Raffaello vatikáni képeit mutatja be. A kortárs képzőművészek közül elsősorban a neoklasszicizmust képviselő meseterek - Bonaventura Genelli, ${ }^{33}$ Friedrich Preller, Bertel Thorvaldsen - kaptak helyet a könyvtárban. ${ }^{34}$ Wéber Antal két gyüjteményes albumot is eladott, ezekben kevésbé ismert képzőmúvészektől válogatott, különféle témájú képek rézmetszeteit közölték. ${ }^{35}$

Négy folyóirat több évfolyamnyi anyaga szerepel a könyvtárában, két építészeti ${ }^{36}$-építészettörténeti témákkal foglalkozó és két iparmúvészeti-iparmúvészettörténeti ${ }^{37}$ folyóirat. $^{38}$

A könyvekben nincsenek bejegyzések, Wéber Antal szignóját is csak három kötetben találjuk meg. Ebből kettő olyan, amelyet elötte más birtokolt, a - sajnos nem kiolvasható - tulajdonos neve át van húzva, alatta látható az aláírás. ${ }^{39}$ Wéber

${ }^{31}$ 6537., 6589., 6606., 6615., 6617., 6543.

32 6593., 6620.

33 A XIX. században nyomtatásban megjelent művei közül egy kivételével - Homer's Illias mind szerepel Wéber könyvtárában.

${ }^{34}$ 6546., 6548., 6549., 6564., 6566., 6567., 6575., 6586., 6588.

35 6550., 6600. Ez utóbbiban a mára már többnyire feledésbe merült alkotók között találjuk Karl Friedrich Schinkelt is, aki egy romantikus tájképpel szerepelt a könyvben.

${ }^{36}$ 6666. havonta megjelenő, elsősorban képeket tartalmaz (1866-78), 6674. havonta megjelenő, sok megépült épület tervét és tervpályázatot ismertetett, rendszeresen foglalkozott praktikus költségvetéskészítési, technológiai, számítási - témákkal is a kortárs építészeten és az építészettörténeten felül (1872-79).

${ }^{37}$ 6536. (1861-78), 6673. (1872-79).

${ }^{38}$ A bekötött példányokról egyelőre nem derült ki, hogy ezekhez előfizetéssel vagy egyszeri vásárlással jutott hozzá Wéber Antal.

$396667 ., 6668$. 
aláirása olvasható a BME Építészettörténeti és Múemléki Tanszékének Könyvtárában található Francesco Zanotto Le fabbriche e i monumenti cospicui di Venezia címü könyvében. A könyv nem szerepel a korabeli leltárkönyvben, feltételezhető, hogy később került a Múegyetemre.

Az 1885-ös magyarországi köz- és magánkönyvtárakat bemutató statisztika ${ }^{40}$ szerint Wéber Antal könyvtára: „Két ezer kötetet meghaladó tulnyomólag müvészeti és müvészettörténelmi jellegü szakkönyvtár, melynek legnagyobb becsét az épitészeti szakmunkák képezik, de ezen felül földrajzi, táj-és népismei, valamint szépirodalmi diszmüvek is nagy számmal fordulnak elö. Van a könyvtárban egy nagy földgömb, 93 térkép, 415 rézmetszet s 598 nagyobb részt mübeccsel bíró fénykép, több magyarországi fürdö és város tájképe." Az adatok alapján feltételezhetjük, hogy 1881-ben Wéber nem teljes könyvtárát adta el és - a statisztika által közölt becsesebb művek jegyzéke szerint ${ }^{41}$ - a gyüjtéssel nem hagyott fel az 1880as évek első felében sem. A kiadás éve szerint csoportosítva - ahol ezt jelölték túlnyomórészt 1881 utáni könyvekkel találkozunk. Ez a lista megközelítőleg sem teljes a megjelölt terjedelem szerint, ${ }^{42}$ azonban így is mutat néhány érdekességet.

Periodikák tekintetében sokkal változatosabb a kép, mint a Múegyetemnek eladott állományban. Megtalálhatóak a magyar, bécsi és berlini építészegyletek közlönyei, melyeket Wéber Antal folyamatosan járatott, egy angol, egy osztrák és egy francia folyóirat, illetve néhány - a Mủegyetemnek eladott - tétel, melyeket a továbbiakban is olvasott folytatólagosan. ${ }^{43}$

A felsorolt könyvek között arányiban elég sok a távoli - japán, ázsiai, arab kultúrákkal foglalkozó munka. ${ }^{44}$ Mivel itt csak válogatásról van szó, nem lehet tudni, hogy csak mint becsesebb múvek kerültek felsorolásra, vagy valóban arányaiban ennyi orientális témát feldolgozó könyvet tartalmazott a könyvtár.

${ }^{40}$ Magyarország köz- és magánkönyvtárai 1885-ben. Szerk.: György Aladár. II. köt. Budapest, Aethaneum, 1886. p. 458.

41 A jegyzék a cikk végén.

42 A bevezetőben említett 2000 kötetnek legfeljebb kéttizedét mutatja be a jegyzék. A terjedelem tekintetében nehéz megítélni, hogy például a folyóiratokat hány kötetként vette figyelembe a statisztika.

${ }^{43}$ A Magyar Mérnök- és Épitészegylet Közlönye. Szerk.: Ambrozovics Béla, Ney Béla, Schwarczel Sándor. Budapest, 1870-85., Publicationen des Vereines ,, Wiener Bauhütte”. Deutsche Bauzeitung. Verkündigungsblatt des Verbandes deutscher Architekten-und Ingenieur Vereine. Szerk.: K. E. O. Fritsch und F. W. Büsing. Berlin, 1875-85.

Külföldi folyóiratok: Allgemeine Bauzeitung mit Abbildungen. Szerk.: Chr. Friedr. Ludw. Förster. Wien, 1845-59., Architectural plates. Building news. Revue generale de l'architecture et des travaux publics. Journal d'architectes. Szerk.: M. César Daly. Paris, 1880-85.

Folytatólagos tételek: 6619., 6673.

${ }^{44}$ Japanischer Ornamentenschatz. Berlin., N. Simakoff: L'art de l'Asie centrale. Recueil de l'art décoratif de l'Asie centrale. St.-Petersburg, 1883., Dr. Gustave Le Bon: La civilisation des Arabes. Paris, 1884. 
Tematikusan folytatva az áttekintést, fontos eltérés a Múegyetemnek eladott állományhoz képest két, az oszloprendeket feldolgozó munka ${ }^{45}$ megléte, és két, a barokkot bemutató könyv. ${ }^{46}$

A 203 kötetnyi részletesen ismert anyag és a közel félszáz tételes 1885-ös jegyzék alapján Wéber Antalt szélesen tájékozott építésznek képzelhetjük el. Életmüvén végigtekintve már a korai, romantikus vörösvári Erdődy-kastélyon is érezhető az elmélyült történeti tudás és biztos formaismeret, ami a későbbiekben kiegyensúlyozott kompozíciós készséggel is párosult. A kissé a klasszikus felé hajló ízlést fedezhetjük fel nagy múvein, az Ádám-palotán, a Szerb-házon és a Halász-házon. Építészetében az előképek ritkán jelennek meg könnyedén felismerhető formában, ${ }^{47}$ a történeti formákat a részletképzéstől a teljes kompozícióig kiegyensúlyozott kreativitással használta.

Wéber Antal könyvtárának anyagát nem csak a tartalom szerint értékelhetjük; érdekes kérdés, hogy a nála lévő könyvek vajon mennyire voltak korszerűek és elterjedtek a maguk korában. Bár a vásárlás évét egy esetben sem ismerjük, a kiadások időpontja némileg eligazíthat a korszerüség kérdésében. ${ }^{48}$ A Múegyetemen lévő mủvek között egy előző századi alkotás van, Piranesi müve. ${ }^{49}$ Ez a gyüjtő antik érdeklődését mutatja, a kötet nem építészeti, hanem múvészeti jelentőségü, egy száz éves könyv talán a XIX. században is jelentős antikvár értékü lehetett. A 101 tétel közül mindössze nyolc származik a század első feléből és csak egy tucat az ötvenes évekből. Dupla annyit adtak ki a hatvanas években, és a gyüjtemény közel fele a hetvenes években készült, a könyvek túlnyomó része első kiadás. ${ }^{50}$ Ezek

45 J. A. Leveil: Traité élémentaire pratique d'architecture ou étude des cinqs ordes d'après Jacques Barozzio de Vignole. Paris., J. M. v. Mauch: Die architektonischen Ordnungen der Griechen und Römer, und der neueren Meister. Berlin, 1862.

${ }^{46}$ L. Baumann, E. Bressler: Barock. Eine Sammlung von Plafonds, Cartouchen, Consolen, Gittern, Möbeln, Vasen, Öfen, Ornamenten, Interieurs, etc. und Monumentalbauten Österreichs aus der Epoche Leopold I. bis Maria Teresia. Wien, 1884-85., Robert Dohme: Barock- und RococoArchitektur. Berlin, 1884.

47 Talán az egyetlen kivétel a Sugár úti Erdődy villa, mely homlokzati kialakításában szinte lemásolja a Caprarolai kis kerti lakot, Vignola alkotását. Az épület két rajza is megtalálható Percier és Fontaine múvében (5660. 74., 75. táblák).

${ }^{48}$ Az elemzésben a Múegyetem könyvtárában megtalálható könyvtári részre támaszkodom, mivel a könyvek közvetlen megtekintése elengedhetetlen a pontos információk feltárásához, például, hogy az adott kötet hányadik kiadás vagy milyen kereskedőn keresztül jutott az építészhez.

A megtekintés nélküli elemzés nehézségét mutatja például, hogy az 1885-ös listában szerepel egy, a Mủegyetem könyvtárának eladott könyvvel egyező leírású tétel (6618.). Pusztán a leírás alapján nem lehet megítélni, hogy ugyanaz-e a könyv, esetleg új kiadás vagy folytatás. A periodikákat sem lehet megtekintésük nélkül tartalmilag elemezni.

Sajnos az 1885-ös lista könyvei egyelőre nem azonosíthatóak. Ha Wéber 1881 után sem látta el rendszeresen kézjegyével könyveit, akkor ez valószínűleg a későbbiekben sem lesz lehetséges.

${ }^{49} 6540$

${ }^{50}$ Kivételek: 6538., 6539., 6540., 6541., 6542. (2. kiadás), 6543., 6544. (3. kiadás). 
alapján nyugodtan mondhatjuk, hogy Wéber Antal könyvtára a maga idejében naprakész volt.

A könyvek elterjedtségét sokkal nehezebb vizsgálni, amíg nem ismerjük több korabeli építész könyvtárát, csak közelítő eredményre juthatunk, de valamelyest eligazíthat minket, hogy a kötetek szerepelnek-e más oktatási intézmények könyvtáraiban Magyarországon és külföldön. ${ }^{51}$ Nagyon népszerünek tünik Eugène Emmanuel Viollet-le-Duc két müve, ${ }^{52}$ melyek a - mai szóhasználattal élve - francia iparmúvészetet és enciklopédiaként a francia építészetet mutatják be a XI.-től a XVI. századig hat, illetve tíz kötetben. Szintén nagyon elterjedt még Paul Marie Letarouilly Édifices de Rome Moderne címü, ${ }^{53}$ Róma újkori építészetét bemutató könyve, melyből csak a BME Építészettörténeti és Müemléki Tanszékének könyvtárában négy példány található. Meglepő, hogy a korszakban - Magyarországon és külföldön is - mennyi helyen megtalálható Joseph Nash múve, ${ }^{54}$ mely angol történeti belső terek tollrajzként készült rekonstrukcióit tartalmazza elsősorban életképek háttereként. Ez a részletes helyszíni felméréseket, szerkesztett részletrajzokat közlő müvekhez képest felületesebb alkotás. Elterjedtnek mondhatjuk még Paul Lacroix, Lewis Gruner, Federigo Lose, Julius Lessing, M. Auguste Racinet, Claude Sauvageot múveit. ${ }^{55}$

Wéber Antal könyvtárának a Mủegyetemi Központi Könyvtárban megtalálható része a legnagyobb átfedést a BME Építészettörténeti és Műemléki Tanszékének könyvtárával mutatja, mely az egyetemi szintű építészképzést kialakító három nagy tanszék - Ókor, Középkor, Újkor - könyvtári anyagainak jó részét őrzi. A könyvek közel harmada megtalálható Bécsben és Münchenben, Berlinben azonban csak nagyon kevés. Talán a korabeli nemzetközi politikai helyzet indokolta, hogy Berlinben csekély számú francia könyvet vásároltak - Wéber könyvtára elsősorban ilyeneket tartalmaz ${ }^{56}$-, a Berlini Akadémia 1893-as katalóguskönyvében nagyon kevés a külföldi építészeti kiadvány. ${ }^{57}$

\footnotetext{
51 Magyarországon a már akkor is létező oktatási intézmények mai könyvtárait és a Magyar Mérnök- és Építészegylet könyvtárának jegyzékét vizsgáltam elsősorban, de az Országos Széchényi Könyvtár központi kézikatalógusa további helyeket is megjelölt mai tulajdonosként. A külföldi könyvtárak közül Bécs, München és Berlin oktatási intézményei szerepeltek a vizsgálatban, ide jutott el a legtöbb magyar építész tanulmányai során a XIX. században.

52 6541., 6542.

${ }^{53}$ 6561. A kötet általános népszerüsége ismert. Sármány Ilona: Historizáló épitészet az Osztrák-Magyar Monarchiában. Corvina, 1990. p. 9.

${ }^{54} 6552$.

55 6543., 6547., 6615., 6617., 6664.

5645 francia, 6 angol, 8 osztrák, néhány olasz és holland kiadvány mellett 34 német könyv is van, a legtöbb lipcsei kiadású.

${ }^{57}$ Katalog der Bibliothek der Königlichen Akademie der Künste zu Berlin. Szerk.: E. Dobbert, W. Grohmann, A. Ascher. Berlin, 1893.
} 
Az építészeti szakirodalom korabeli magyarországi terjesztéséről nagyon keveset tudunk, ${ }^{58}$ egyelöre arra támaszkodhatunk, amit a könyvekből és borítójukról kiolvashatunk. A Kiegyezés után jelentősen fellendült a magyarországi könyvkereskedelem, ${ }^{59}$ de lehetséges, hogy Wéber más Monarchia-beli kereskedőktől vásárolt, vagy akár a kiadóktól rendelhetett. ${ }^{60} \mathrm{~A}$ kötetekben - általában a borítók belső oldalán - található vignetták és pecsétek adhatnak némi útmutatást a terjesztőkre vonatkozóan. Feltételezhetjük, hogy a párizsi Ducher és Morell kiadók könyvei a Kolowrat Ringen álló Müller Könyvkereskedésen ${ }^{61}$ keresztül juthattak Magyarországra, már bekötött formában. Wéber Antal könyvein megtalálható még a berlini Friedhändler \& Sohn, ${ }^{62}$ Ernst Wasmuth, ${ }^{63}$ a bécsi Lehman \&Wentzel, ${ }^{64}$ Müller ${ }^{65}$ kereskedők neve és címe (3. ábra).

Néhány - tokban terjesztett - kiadványt valószínúleg már magyar könyvkötők kötöttek be ${ }^{66} \mathrm{~A}$ XIX. század második felében általános volt még a füzetlen-kötetlen kiadványok terjesztése, ezeket megvásárlás után a tulajdonos saját könyvtárához igazított gerinccel és borítóval köttette be. ${ }^{67}$ Az oktatási intézmények könyvtáraiba $^{68}$ - ha nem hagyatékok, hanem saját vásárlás útján gyarapodtak - elsősorban

${ }^{58}$ A könyvkereskedelmet feldolgozó szakirodalom a magyar kultúra fejlődésével, elsősorban szépirodalmi könyvek terjesztésével és a cenzúra kérdésével foglalkozik, az építészeti szakirodalomra vonatkozóan nemigen találunk utalást.

59 1873-ban, az egyesítés évében Budapesten már 41-en forgalmaztak könyveket. Pogány György: A magyar könyvkereskedelem rövid története. Hatágú Síp Alapítvány, Budapest, 2004. p. 69.

${ }^{60}$ 6619. tartalomjegyzék köteten Wéber neve „címzettként” szerepel.

${ }^{61}$ 6556., 6610., 6612., 6664. II., III., IV. köteteken Libraire de A. Morel Paris, L. Müller Vienne Kolowrat Ring 9., 6619. tartalomjegyzék köteten Libraire Ducher \& $C^{E}$ A Paris, L. Müller Vienne Kolowrat Ring 9. A különböző kereskedések neve egy matricán.

${ }^{62}$ 6562. I. köteten R. Friedhändler \& Sohn Berlin Friedrichstrasse101.

63 6607. Ernst Wasmuth Architektur-Buchhandlung Berlin Werder Strasse 6.

${ }^{64}$ 6562. III., IV. köteten, 6594. Buchhandlung für Technik und Kunst Lehman \& Wentzel Wien Kärtnerstrasse 40.

${ }^{65}$ 6585. L. Müller Vienne Kolowrat Ring 9., önállóan.

${ }^{66}$ 6703. tétel bizonyosan ilyen, melyben Merkl Lajos komáromi könyvkötő mester vignettája van. Valószínűsíthetően ebbe a körbe tartoztak az egységesen, de nem minden esetben évfolyamonként kötött folyóiratok is (6536., 6666.). Mivel a kötetek jó részét állagmegóvás miatt újrakötötték, már nem deríthetö ki, hogy vajon Wéber Antal egységesen köttette-e könyveit. Ennek ismerete nélkül a kiadási évszámok alapján nagyon valószínűnek látszik, hogy könyveinek nagy részét nem „használtan” szerezte be.

${ }^{67}$ Ebben az időszakban a nyomdászat, kiadás és könyvkötés még elváltak egymástól, az addig különbözőnek számító tevékenységek a század végén egyesültek a könyvszakma fellendülésével és a nagy kiadók megjelenésével párhuzamosan. Kókay György: A könyvkereskedelem Magyarországon. Balassi Kiadó, Budapest, 1997. pp. 110-121.

${ }^{68}$ Királyi József Műegyetem Könyvtára, Országos Magyar Iparművészeti Múzeum és Iskola Könyvtára és az Országos Magyar Rajztanoda és Rajztanárképezde Könyvtárának vizsgálata alapján. 

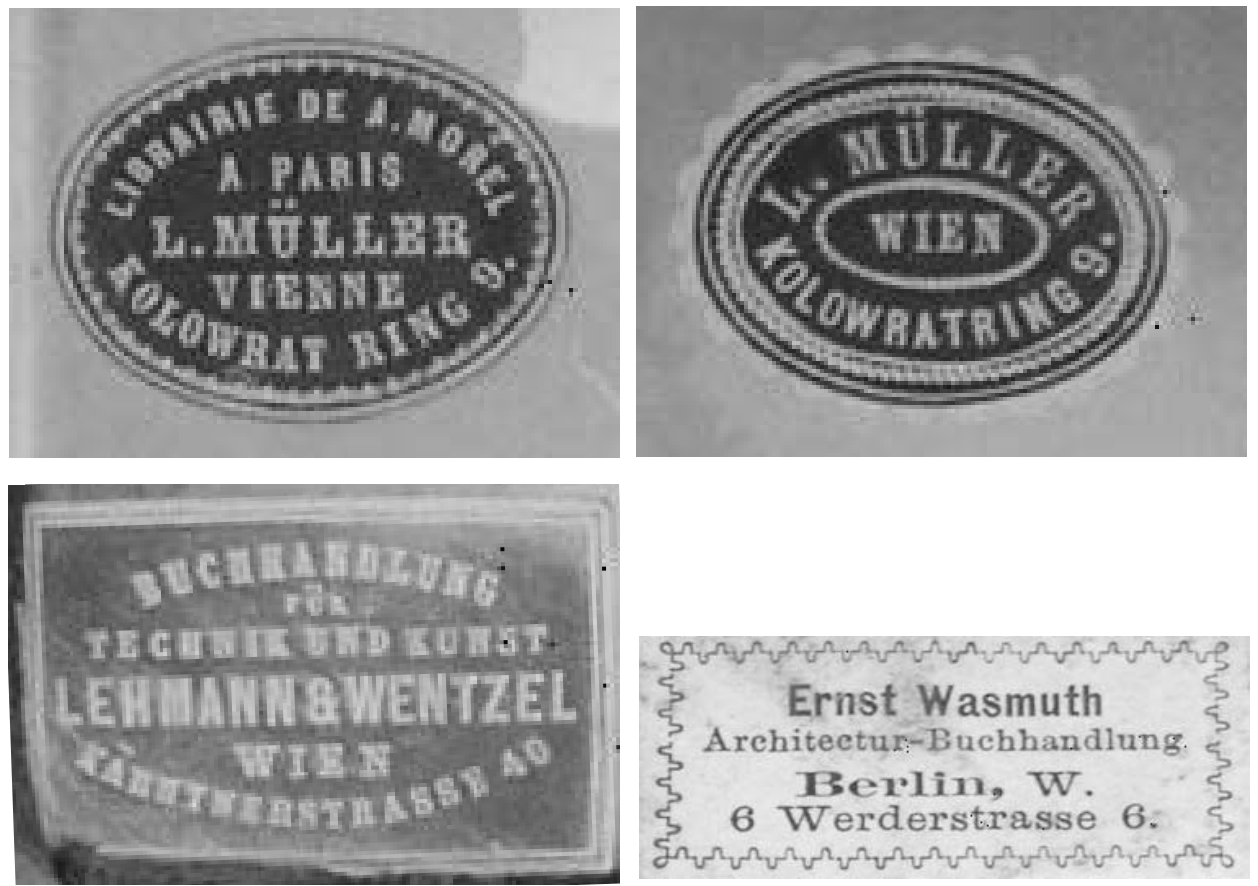

3. ábra. Könyvkereskedők címe Wéber Antal könyvein

kötés nélkül kerültek a nagy albumok. A lapokat összefogó kötős mappák hátoldalán a kiadók további kiadványaikat reklámozták, de nem volt ritka, hogy a könyvekhez mellékelve kis füzetben elküldték korábbi kiadványaik listáját. ${ }^{69}$ Az újdonságokról ezen kívül az építészek tudomást szerezhettek a szakfolyóiratokból is. Rendszeresen közölt ismertetéseket - a Wéber Antalnak járó külföldi kiadványok közül - a Blaetter für Kunstgewerbe, ${ }^{70}$ az itt ismertetett múvek közül a könyvtárban nyolcat meg is találunk. ${ }^{71}$

Wéber Antal könyvtárának elemzése megvilágítja a kor egy nagy építészének múveltségét, a korszak építészeti szakirodalmáról alkotott képünk más építészek könyvtárainak megismerésével mélyülhet el. A XIX. század második felének építészeti szakirodalom-kutatásában további érdekességeket rejthet a külföldi és ma-

${ }^{69}$ A 6605-ös tétel Képzőművészeti Egyetem Lyka Károly Könyvtárában található példányában még megvan egy ilyen füzetke: Prospect. Verlag von F. A. Brockhaus in Leipzig Internationale Wissentschaftliche Bibliothek. A kiadványok címén és témáján kívül megadja hivatalos külföldi terjesztőit is, magyarországi terjesztő nem szerepel a listában.

${ }^{70} 6673$.

${ }^{71}$ Az ismertetés sorrendében: 6596., 6703., 6589., 6617., 6662., 6608., 6541. 
gyar intézmények korabeli katalógusainak összehasonlítása, de az egyes építészek műveltségének megismerését - szerencsésen felbukkanó - teljes hagyatékuk tanulmányozása jelentheti. ${ }^{72}$

\section{WÉBER ANTAL KÖNYVTÁRA A MŰEGYETEMEN JEGYZÉK ${ }^{73}$}

Az egyes tételek az eredeti leltári számokkal a bevétel sorrendjében szerepelnek.

A további példányok feltalálási helyeit jelző rövidítések: ${ }^{74}$

BME - Budapesti Múszaki és Gazdaságtudományi Egyetem Központi Könyvtára

BME ÉT - Budapesti Müszaki és Gazdaságtudományi Egyetem Építészettörténeti és Müemléki Tanszékének könyvtára

DE - Debreceni Egyetem Egyetemi és Nemzeti Könyvtár

ELTE - Eötvös Lóránd Tudományegyetem Egyetemi Könyvtár

FSZEK - Fővárosi Szabó Ervin Könyvtár

IMEK - Iparmüvészeti Egyetem Könyvtára

IMK - Iparmüvészeti Múzeum Könyvtára

KE LKK - Képzőmúvészeti Egyetem Lyka Károly Könyvtára

ME - Miskolci Egyetem Könyvtár, Levéltár, Múzeum

MMÉ - Magyar Mérnök- és Építészegylet Könyvtára

MNG - Magyar Nemzeti Galéria Könyvtára

MNM - Magyar Nemzeti Múzeum Központi Könyvtára

MTA - Magyar Tudományos Akadémia Könyvtára

MTAI - Magyar Tudományos Akadémia Irodalomtörténeti Könyvtár

72 A XIX. századi építészeti szakkönyvek jelentős antikvár forgalmából is előkerülhet egyegy építész hagyatékának néhány azonosítható darabja.

${ }^{73}$ A leltári számok folyamatossága megszakad, a Wébertől származó kötetek számbavétele közben egyéb helyről származó köteteket is leltároztak. A szerzők és a könyvek címei a köteteken olvasható írásmód szerint szerepelnek.

${ }^{74}$ Az Országos Széchényi Könyvtár Központi Kézikatalógusa, Az Országos Magyar Királyi Mintarajziskola és Rajztanárképző Könyvtárának czimjegyzéke. Szerk.: Várdai Szilárd, Budapest, 1900., Az Országos Magyar Iparmüvészeti Múzeum és Iskola Könyvtárának czimjegyzéke. Szerk.: Czakó Elemér, Budapest, 1900., A Magyar Mérnök- és Épitészegylet könyvtárának cimjegyzéke. Szerk.: Czekelius Aurél, Mihályfi József. Budapest, 1896. pp. 34-35., A Magyar Mérnök- és Épitészegylet könyvtárának címjegyzéke. Szerk: Jendrássik Kornél. Budapest, 1917. pp. 110-168. és az egyes könyvtárak digitális katalógusa szerint, az eredeti tulajdonosok a belső címlapok bejegyzései alapján.

Elképzelhető, hogy a fenti listában szereplő tételek további könyvtárakban is fellelhetőek, az OSZK Központi Kézikatalógusához képest a végigjárt budapesti könyvtárakban jelentős eltéréseket találtam.

Abban az esetben, ha a könyvtár (illetve intézményi elődje) már 1900-ban bizonyosan rendelkezett a könyvvel, a könyvtár rövidítése félkövéren szedve.

Munkámban nyújtott segítségükért köszönetemet fejezem ki az OSZK, BME, BME ÉT, IMK, KE LKK könyvtárak munkatársainak. 
MTM - Magyar Természettudományi Múzeum Könyvtára

NYME - Nyugat Magyarországi Egyetem, Központi Könyvtár

OSZK - Országos Széchényi Könyvtár

PTE - Pécsi Tudományegyetem Központi Könyvtára

SZM - Szépmúvészeti Múzeum Könyvtára

SZTE - Szegedi Tudományegyetem Központi Könyvtár

A külföldön fellelhető példányokat annak a három városnak az egyetemi könyvtáraiban vizsgáltam, ahová a legtöbb magyar XIX. századi építész eljuthatott tanulni. ${ }^{75}$

Bécs: Technische Universität (Politechnikum utóda), Akademie für Bildende Künste

Berlin: Akademie der Künste

München: Technische Universität, Akademie der Bildenden Künste

6536

L'art pour tous. Encyclopédie de l'art industriel et décoratif. Szerk.: Émile Reiber, Claude Sauvageot. A. Morell, Paris, 1861-78.

További példányok: KE LKK, MMÉ (hiányos), München

6537

Felix Lay: Die Verbreitung und Cultur der Südslaven. Leipzig, 1871.

További példányok: KE LKK, München

6538

M. César Daly: L'architecture privée au XIXe. siècle. Décorations intérieures peintes. Ducher, Paris, 1872-77.

\section{9}

M. César Daly: Motifs historiques d'architecture et de sculptur d'ornement. Décorations intérieures emprentées et des édifices français du commencement de la renaissance à la fin Louis XIV. Ducher, Paris, 1870-80.

További példányok: BME ÉT, IMK, MMÉ, Bécs

6540

Giovanni Battista Piranesi: Vase e candelabri, cippi, sarcofagi, tripodi lucerne ed ornamenti antichi. 1778 .

További példányok: BME ÉT, KE LKK, IMK

6541

Eugene Emmanuel Viollet-le-Duc: Dictionnaire raisonné du mobilier français de l'époque carlovingienne à la renaissance. A. Morell, Paris, 1871-75.

További példányok: KE LKK, IMEK, FSZEK, MTA, MTAI, MNG, SZM, PTE, Bécs, München

75 Österreichischer Bibliothekenverbund Online Gesamtkatalog, Archiv der Akademie der Künste Online katalógus, Katalog der Bibliothek der Königlichen Akademie der Künste zu Berlin. Szerk.: E. Dobbert, W. Grohmann, A. Ascher. Berlin, 1893. Bayerischer Bibliothekenverbund Online Katalog alapján. 


\section{2}

Eugene Emmanuel Viollet-le-Duc: Dictionnaire raisonné de l'architecture française du XIe au XVIe siècle. A. Morell, Paris, 1867-70.

További példányok: BME ÉT, KE LKK, IMK, MMMÉ, MTA, MTAI, PTE, SZTE, Bécs, Berlin, München

6543

Paul Lacroix: XVIII.me siècle. Institutions usages et costumes France 1700-1789. Firmin - Didot, Paris, 1875.

További példányok: BME ÉT, KE LKK, OSZK, FSZEK, MTA, ELTE, DE

\section{4}

Franz Reber: Die Ruinen Roms und der Campagna. T. O. Weigel, Leipzig, 1863.

További példány: Bécs

6545

Carl Alexander Heideloff, Heinrich Leibnitz: Die Kunst des Mittelalters in Schwaben. Denkmäler der Baukunst, Bildnerei und Malerei. Ebner \& Seubert, Stuttgart, 1855.

További példányok: BME ÉT (eredeti tulajdonos: Steindl Imre), MMÉ, München

6546

Bonaventura Genelli: Umrisse zum Homer. J. B. Cottaschen, Stuttgart, 1866.

További példányok: DE, Berlin, München

6547

Lewis Gruner, Federigo Lose: The terra-cotta architecture of north Italy. XII.-XV. centuries. Elöszó:

V. Ottolini. John Murray, London, 1867.

További példányok: BME ÉT, MTA, Berlin

\section{8}

Friedrich Preller: Homer's Odyssee. Vossische Übersetzung. Alphons Dürr, Leipzig, 1872.

Wéber Antal kötete lappang, további példányok: KE LKK, Bécs

\section{9}

Bonaventura Genelli: Umrisse zu Dante’s Göttlicher Komödie. Alphons Dürr, Leipzig, 1867.

További példányok: KE LKK, Berlin, München

6550

Sammlung von Original Radirungen Düsseldorfer Künstler. V. W. Schulgen, Düsseldorf, Paris, é. n.

6551

M. Georges Rohault de Fleury: Monuments de Pise au moyen âge. A. Morell, Paris, 1866.

6552

Joseph Nash: Mansions of England in the Olden Time. Henry Sotheran \& Co., London, 1869-72.

További példányok: BME ÉT, KE LKK, IMK, IMEK, ELTE, MNM, PTE, DE, Bécs, Berlin 


\section{3}

Eugene Rouyer, Alfred Darcel: L'art architectural en France. Motifs de décoration intérieure et extérieure. Liege, 1866-67.

További példányok: Bécs, München

6554

Lewis Gruner: Decorations of the Garden-Pavillon in the Grounds of Buckingham Palace. Murray, Longman \& Co., P \& D Colnaghi, F. G. Moon, L. Gruner, London, 1856.

\section{5}

Arthur Mangin: Les jardins. Histoire et description. Alfred Mame, Tours, 1867.

\section{6}

Luigi Canina: L'architettura antica. Descritta e dimostrata coi monumenti, opera divisa in tre sezioni risguardanti la storia, la teorica e le pratiche dell'architettura egiziana, greca e romana. Roma, 1834-44.

További példányok: BME ÉT, KE LKK, München

\section{7}

Eugene Rouyer: Les appartements privés de S. M. l'Impératrice au palais des Tuileries. Baudry, Paris, 1867.

Wéber Antal kötete lappang, további példány: München

\section{8}

Owen Jones: Plans Elevations, Sections, and Details of the Alhambra. From Drawings Taken on the Spot in 1834 by the Late M. Jules Goury and in 1834 and 1839 by Owen Jones. London, 1842, 1845.

További példány: IMK

\section{9}

M. E. Isabelle: Les édifices circulaires et les dömes. Didot, Paris, 1855.

További példányok: BME ÉT, Berlin

6560

Percier et Fontaine: Choix des plus célèbres maisons de plaisance de Roma et de ses environs. Didot, Paris, 1824.

További példány: München

\section{1}

Paul Marie Letarouilly: Édifices de Rome Moderne. Bance, Paris, 1856.

További példányok: BME ÉT, KE LKK, IMK, MMÉ, ELTE, SZM, SZTE

\section{2}

J. Stuart, N. Revett: Die Alterthümer zu Athen. Carl Wilhelm Leske, Leipzig, Darmstadt, 1829-31. További példányok: BME ÉT, MMÉ, FSZEK, Bécs, München 
6563

The unedited antiquites of Attica. Comprising the architectural remains of Eleusis, Rhamnus, Sunium and Thoricus. Longman, Hurst, Rees, Orme and Brown, Paternoster-Row and Murray, London, 1817.

További példányok: IMEK, Bécs, München

6564

Bonaventura Genelli: Satura - Compositionen. Alphons Dürr, Leipzig, 1871.

További példányok: BME ÉT (eredeti tulajdonosok: Kálmán-Ulmann), KE LKK, MMÉ, MTA, München

6565

Auguste-Henry-Victor Grandjean de Montigny, Auguste Famin: Renaissance Italienne. Architecture Toscane. Palais, maisons, églises et autres édifices publics et privés principalment des XVe, XVIe et XVIIe siècle. Ducher, Paris, 1874.

További példányok: BME ÉT (eredeti tulajdonos: Schmahl Henrik), KE LKK, IMK, MMÉ

6566

Friedrich Preller: Figuren-Fris zur Odyssee. Előszó: Max Jordan. Alphons Dürr, Leipzig, 1875.

További példányok: KE LKK, SZM, München

\section{7}

Hermann Lücke: Der Einzug Alexander des Grossen in Babylon. Marmorfries von Bertel Thorwaldsen. Alphons Dürr, Leipzig, 1870.

További példány: Bécs

\section{8}

William Wilkins: Antiquities of Magna Graecia. Longman, Hurst, Orme and Rees, Cambridge, 1807.

További példány: München

6569

Ernst Förster: Denkmale Deutscher Baukunst. Von Einführung des Christenthums bis auf die neuste Zeit. T. O. Weigel, Leipzig, 1858-70.

További példányok: BME ÉT, FSZEK, MMÉ, München

6570

Machines Borde. Paris, 1858.

Wéber Antal kötete lappang

6571

Friedrich Arnold: Der Herzogliche Palast von Urbine. T. O. Weigel, Leipzig, 1857.

6572

Karl Friedrich Schinkel: Entwurf zu einem Königspalast auf der Akropolis zu Athen. Ernst \& Korn, Berlin, 1862.

További példányok: BME ÉT, Bécs 
6573

Karl Friedrich Schinkel: Entwurf zu dem Kaiserlichen Palast Orianda. Ernst \& Korn, Berlin, 1862.

További példány: Bécs

\section{4}

Karl Friedrich Schinkel: Sammlung Architektonischer Entwürfe. Enthaltend theils Werke welche ausgeführt sind theiles Gegenstände deren Ausführung beabsichtigt wurde. Ernst \& Korn, Berlin, 1866.

További példányok: BME ÉT, Bécs

6575

Bonaventura Genelli: Das Leben einer Hexe in Zeihnungen. elöszó: Hermann Ulrici. Buddeus, Weigel, Düsseldorf, Leipzig, 1850.

További példány: Bécs

6576

Bonfils: Architecture antique. Égypte, Grèce, Asie Mineure. Ducher, Paris, 1872.

További példányok: BME ÉT, KE LKK

6577

Charles Garnier: Le nouvel opéra de Paris. Statues décoratives groupes et bas-reliefs. Ducher, Paris, 1875.

További példányok: BME ÉT, KE LKK, MMÉ

6578

Charles Garnier: Le nouvel opéra de Paris. Bronzes candélabres, lustres torchères appliques lampadaires. Ducher, Paris, 1875.

További példányok: BME ÉT, KE LKK, MMÉ

\section{9}

Charles Garnier: Le nouvel opéra de Paris. Peintures décoratives, plafonds, panneaux, voûtes, tympans. Ducher, Paris, 1875.

További példányok: BME ÉT, KE LKK, MMÉ

6580

E. le Nail: Architecture de la renaissance. Le Château Blois. Extérieur et intérieur. Ensembles ornementale, décoration, peintes, tentures, plafonds, carrelages. Ducher, Paris, 1875.

További példányok: BME ÉT (eredeti tulajdonos: Hültl Dezső), IMK, MMÉ, Bécs

6581

Tony Desjardins: Monographie de l'Hötel-de-Ville de Lyon. Restauré sous l' administration MM. Vaïsse et Chevreau, Senateurs Accompagnée d'un texte historique et descriptif. A. Morell, Paris, 1867.

6582

Paul Vredeman de Vriese: Plusieurs menuiseries comme portaux, garderobes, buffets, châlicts, tables, arches, selles, bancs, escabelles, rouleaux appendre tonailles et beaucoup d'autres sortes d'ouvrages. G-A. Van Trigt, Brussels, 1869.

Wéber Antal kötete lappang, további példány: KE LKK 


\section{3}

Carl Timler: Die Renaissance in Italien. Architektonisches Skizzenbuch. T. O. Weigel, Leipzig, 1865. További példányok: KE LKK, MMÉ, München

\section{4}

M. Rodolphe Pfnor: Châteaux de la renaissance. Monographie du palais de Fontainebleau. A. Morell, Paris, 1873.

További példányok: BME ÉT (eredeti tulajdonos: Magyar Mérnök- és Építészegylet), IMK, MNG, Bécs

\section{5}

Renaissance Italienne. Architecture et décoration. Décorations murales, plafonds, voütes, mosaiques, ect. Ducher, Paris, 1875.

További példányok: BME ÉT (eredeti tulajdonos: Hauszmann Alajos), KE LKK

6586

Bonaventura Genelli: Aus dem Leben eines Wüstlings. Text und Atlas. Brockhaus, Leipzig, 1866.

Wéber Antal kötete lappang

6587

Victor Calliat: Hötel de Ville de Paris. l'Auteur, Carilian-Goeury, Victor Dalmont, Paris, 1844-59. Wéber Antal kötete lappang, további példányok: BME ÉT, MMÉ, FSZEK

\section{8}

Bonaventura Genelli: Aus dem Leben eines Künstlers. Előszó: Max Jordan. Alphons Dürr, Leipzig, 1868.

További példányok: KE LKK, Berlin, München

6589

Valentin Teirich: Ornamente aus der Blütethezeit Italienischer Renaissance. Intarsien. Verlag der Beckschen-Universitäts Buchhandlung Alfred Hölder, Wien, 1873.

További példányok: KE LKK, MMÉ, Bécs

6590

Meubles et objets d'art des XV-XVI-XVIIe siècles. Goupil, Paris, 1871.

További példány: MMÉ

6591

Pini: Raccolta di ornamenti rari. é. n.

6592

Conrad von Dollinger: Architektonische Reise-Skizzen aus Deutschland Frankreich und Italien. Konrad Wittwer, Stuttgart, 1872-80.

További példányok: BME ÉT, MMÉ, KE LKK, IMEK, Berlin

6593

G. Arosa: Grand autel des douze Dieux Musée du Louvre. A. Morell, Paris, 1870. 


\section{4}

Jules Bouchet: Compositions antiques. Dessinées, gravées et publiées. l'Auteur, Paris, 1851.

További példány: BME ÉT

\section{5}

Concours d'Architecture. J. Baudry, Paris, é. n.

További példány: KE LKK

\section{6}

Hittenkofer: Formen-Elemente aus der gesamten Ornamentik. Für Architekten, Bauwerkmeister, Kunst- und Gewerbetreibende ect. sowie für Akademiker, Politechniker, Bau und Gewerbewschüler. Carl Scholze, Leipzig, 1871.

További példányok: IMEK, ME, Bécs

6597

Julius Carl Raschdorff: Entwürfe und Bauausführungen im Stile Deutscher Renaissance. Ernst Wasmuth, Berlin, 1879.

További példány: IMK, MMÉ

6598

M. A. Magne: Monographie du nouveau théâtre du Vaudeville. Ducher, Paris, 1873.

6599

Fragments d'Architecture antique. Baundry, Paris, é. n.

További példányok: BME ÉT, KE LKK, MMÉ, Bécs

6600

Album moderner Meister. Zwanzig Radierungen und Kupferstichen aus der Zeitschrift für Bildende Kunst ausgewählt. A. Seemann, Leipzig, 1871.

6601

Valentin Teirich: Cabinet (Kunstschrank) im auftrage Sr. Majestät Franz Joseph I. Waldheim, Wien, 1874.

6602

Bauschatz. Eine Sammlung hervorragender Bauwerke, Details etc. Lehrmann \& Wenzel, Wien, 1879.

További példányok: IMK, PTE, München

6603

A. Siccardsburg, I. Stock, G. Gugitz, F. Paulick: Die Thür- und Fernster-Verschlüsse nach ihrer technischen Entwicklung in den verschiedenen Ländern bis auf neueste Zeit. Lehrmann \& Wenzel, Wien, 1876.

További példányok: PTE, Bécs, München

6604

Franz Rudolf Alt: Wien im Weltausstellungsjahre 1873. Eduard Hölzer, Wien, 1873. 
6605

Eugene Emmanuel Viollet-le-Duc: Habitations modernes. A. Morell, Paris, 1875, 1877.

További példányok: KE LKK, IMK, Bécs, München

\section{6}

M. Dupont-Auberville: Art industriel. L'ornement des tissus. Ducher, Paris, 1877.

További példány: BME ÉT

\section{7}

M. Giovanni Iannoni: Saggi di architettura e decorazione Italiana. Enrico Maccari, Roma, é. n.

További példányok: KE LKK, Bécs

6608

Léon Parvillée: Architecture et décoration turques au XVe siècle. A. Morell, Paris, 1874.

További példány: KE LKK

6609

César Daly: Architecture funéraire contemporaine. Spécimens de tombeaux. Chapelles funéraires, mausolées, sarcophages, stèles, pierres tombales, croix. Ducher, Paris, 1871.

6610

César Daly, Gabriel Davidoud: Architecture contemporaine. Les théâtres de la place du Châtelet. Théâtre du Châtelet, Théâtre Lyrique. Ducher, Paris, 1874.

További példány: BME ÉT (eredeti tulajdonos: Steindl Imre)

6611

Friedrich Maximilian Hessemer: Arabische und Alt-Italienische Bau-Verzierungen. Dietrich Reimer, Berlin, 1841.

További példány: MMÉ

6612

Daniel Ramée, Rodolphe Pfnor: Monographie du château de Heidelberg. Palais de Otto Henry, Pavillon de Féderic-le Sage. A. Morell, Paris, 1859.

További példányok: BME ÉT, KE LKK, MMÉ, Bécs

6613

Die prämiirten Entwürfe der Hamburger Rathaus-Concurrenz 1876. Concurrenz ausschreiben und Gutachten der Comission. Stumper, Hamburg, 1877.

További példányok: BME ÉT, KE LKK, MMÉ, IMEK, PTE

6614

Michel Liénard: Spéciment de la décoration et de l'ornementation au XIXe siècle. Claeseu, Pilon, Liége, Paris, Berlin, 1872.

További példányok: KE LKK, MMÉ

6615

Julius Lessing: Alt Orientalische Teppichmuster. Ernst Wasmuth, Berlin, 1877. További példányok: BME ÉT, FSZEK, IMEK, MTA, SZTE, Bécs 
6616

Rene Dardel: Monographie du palais du commerce élévé à Lyon. A. Morell, Paris, 1868.

További példány: BME ÉT

\section{7}

M. Auguste Racinet: L'ornement polychrome. Art ancien et asiatique, moyen âge renaissance, XVIIe et XVIIIe siècle. Recueil historique et pratique. Firmin - Didot, Paris, 1869.

További példányok: BME ÉT, KE LKK, IMK, IMEK, FSZEK, MMÉ, Bécs, Berlin

\section{8}

Hugo Licht: Architektur Deutschlands. Übersicht der Hervorragendsten Bauausführungen der Neuzeit. Előszó: A. Rosenberg. Ernst Wasmuth, Berlin, 1879.

\section{9}

M. M. Wulliam, Farge: Le recueil d'architecture choix de documents pratiques. Ducher, Paris, $1874-78$.

További példányok: MTM, MMÉ

6620

L. Koch: Rafaels Loggien in Vatican zu Rom. L. Koch, Wien, 1878.

További példányok: KE LKK, PTE, Bécs

6662

G. F. Seidl: Die königliche Residenz in München. E. A. Seemann, Leipzig, 1880.

6663

Tito Vespasianus Paravicini: Die Renaissance-Architektur der Lombadei. Előszó: George Gilbers. Dresden, é. $n$.

További példányok: BME ÉT, IMK, MMÉ

6664

Claude Sauvageot: Palais, châteaux, hôtels et maisons de France. A. Morell, Paris, 1867.

További példányok: BME ÉT, IMK, MMÉ, Bécs, München

6665

Neubauten zu Frankfurt am Main. Heinrich Keller, Frankfurt, 1878.

További példány: BME ÉT (eredeti tulajdonos: Hauszmann Alajos)

6666

Croquis d'architecture. Szerk.: Gustave Raulin. Ducher, Paris, 1866-78.

További példányok: BME ÉT, Berlin

6667

Alterthümer von Jonien. Carl Wilhelm Leske, Leipzig, é. n.

További példány: MMÉ 
6668

Alterthümer von Attika. Carl Wilhelm Leske, Leipzig, Darmstadt, é. n.

További példányok: MMÉ, München

6669

Eugéne Prignot: L'architecture la décoration et l'ameublement. Soixante compositions et dessins inédits. C. Claesen, Paris, Liége, Berlin, 1867.

További példányok: BME (eredeti tulajdonos: Kéler Napóleon), BME ÉT, IMEK

6670

Léopold-Camille Cernesson: Grammaire élémentaire du dessin. Ouvrage destiné à l'enseignement méthodique et progressif du dessin appliqué aux arts. Ducher, Paris, 1877.

További példány: KE LKK

6671

Henry Revoil: Architecture romane du midi de la France. Dessinée, mesurée et décrite. A. Morell, Paris, 1867-74.

További példányok: BME ÉT (eredeti tulajdonos: Steindl Imre), KE LKK

6672

C. von Lützow, Ludwig Tischler: Wiener Neubauten. Lehrmann \& Wenzel, Wien, 1876-80.

További példányok: KE LKK, MMÉ, NYME, München

6673

Blaeter für Kunstgewerbe. Szerk.: Valentin Teirich, Josef Storck. R. von Waldheim, Wien, 1872-79. További példányok: MMÉ, München

6674

Encyclopédie d'architecture. Revue mensuelle des travaux publics et particuliers. A. Morell, Paris, 1872-78.

További példány: KE LKK

6703

August Ortwein, August Schiffers: Deutsche Renaissance. Eine Sammlung von Gegenständen der Architektur, Decoration und Kunstgewerbe in Original Aufnahmen. A. E. Seemann, Leipzig, 1871-81.

További példányok: BME ÉT, IMK, MMÉ

Francesco Zanotto: Le fabbriche e i monumenti cospicui di Venezia. előszó: Antonio Diedo. Giuseppe Antonelli, Luciano Basadonna, Venezia, 1858.

További példányok: BME ÉT, IMK, MMÉ, München 


\section{WÉBER ANTAL KÖNYVTÁRÁNAK BECSESEBB DARABJAI 1885-BEN Jegyzék $k^{76}$}

Erasmo Pistolesi: Il Vaticano. Roma. 1829-38.

Hessen-Homburgisches neu vollständiges Gesang. Homburg vor der Höh, 1734.

Leopold Gmelin: Die Elemente der Gefässbildnerei mit besonderer Berücksichtigung der Keramik. München, 1885.

Fünfzig Handzeichnungen alter Meister.

Friedrich Jaennicke: Grundriss der Keramik in Bezug auf das Kunstgewerbe. Eine historische Darstellung ihres Entwicklungsganges in Europa, dem Orient und Ost-Asien von den ältesten Zeiten bis auf die Gegenwart. Stuttgart, 1879.

Dr. P. F. Krell: Die Klassiker der Malerei. Stuttgart, 1876.

Spanische Künstler-Mappe zu Gunsten der Nothleidenen in Spanien. München, 1855.

Japanischer Ornamentenschatz. Berlin.

N. Simakoff: L'art de l'Asie centrale. Recueil de l'art décoratif de l'Asie centrale. St.-Petersburg, 1883.

Dr. Gustave Le Bon: La civilisation des Arabes. Paris, 1884.

J. Fischbach, H. Marins: Deutscher Wald und Hain in Bild und Wort. München, Berlin.

Woldemar Kaden: Das Schweitzer Land. Eine Sommerfahrt durch Gebirg und Tahl. Stuttgart.

M. Pichon: Nouveau plan routier de la ville et faubourgs de Paris. Avec ses Principaux édifices et nouvelles barrières. Paris, 1790.

Franz Zanotto, Joseph Ludwig Gatteri: Geschichte Venedigs in 150 Kupfertafeln nach Chronicken, geschichlichen Thatsachen und dem Costum der Zeit. Venedig, 1863.

Franz Zanotto, M. Moro, J. Rebellato: Das malerische, monumentale, historische und artistische Venedig. Eine Darstellung seiner Haupt-Ansichten und alten Gebräuche. Venedig, 1857.

Architektonische Rundschau. Skizzenblätter aus allen Gebieten der Baukunst. Stuttgart, 1885.

Architectural plates. Building news.

L. Baumann, E. Bressler: Barock. Eine Sammlung von Plafonds, Cartouchen, Consolen, Gittern, Möbeln, Vasen, Öfen, Ornamenten, Interieurs, etc. und Monumentalbauten Österreichs aus der Epoche Leopold I. bis Maria Teresia. Wien, 1884-85.

Allgemeine Bauzeitung mit Abbildungen. Szerk.: Chr. Friedr. Ludw. Förster. Wien, 1845-59.

Deutsche Bauzeitung. Verkündigungsblatt des Verbandes deutscher Architekten-und Ingenieur Vereine. Szerk.: K. E. O. Fritsch und F. W. Büsing. Berlin, 1875-85.

Blätter für Kunstgewerbe. Szerk.: Josef Storck. Wien, 1880-81.

Ernest Bosco: Dictionnaire raisonné d'architecture et des sciences et arts qui s'y rattachent. Paris, $1877-78$.

${ }^{76}$ Magyarország köz- és magánkönyvtárai 1885-ben. Szerk.: György Aladár. II. köt. Budapest, Aethaneum, 1886. p. 458. alapján. (A tételek az eredeti közlés sorrendjében, az ott közölt adatokkal szerepelnek.) 
Pierre Chabat: La brique et la terre cuite. Etude historique de l'emploi de ces matériaux, fabrication et usages. Motifs de construction et decoration choisis dans l'architecture des différents peuples. Paris, 1881.

M. Cesar Daly: Motifs divers de serrurerie. Extrait de la Revue générale de l'architecture et des travaux publics et de divers autres ouvrages. I. Partie Serrurerie ancienne. I. Partie Serrurerie moderne. Paris.

Robert Dohme: Barock- und Rococo-Architektur. Berlin, 1884.

Encyclopèdie d'architecture. Paris, 1880-85.

Budapest Épitményei. Szerk.: Rozinay István. Budapest, 1883.

K. E. O. Fritsch: Denkmäler deutscher Renaissance. Berlin, 1882-85.

Karl Gropius: Ornamente in verschiedenen Baustylen für Architekten und Maler.

Ludwig Klasen: Grundriss-Vorbilder von Gebäuden aller Art. Leipzig, 1882-84.

Otto Lessing: Ausgeführte Bauornamente der Neuzeit. Sammlung hervorragender Ornamentausführungen der bedeutesten Architekten und Bildhauer in Deutschland und Österreich. Berlin, 1884.

J. A. Leveil: Traité élémentaire pratique d'architecture ou étude des cinqs ordes d'après Jacques Barozzio de Vignole. Paris.

Hugo Licht: Architektur Deutschlands. Übersicht der hervorragendsten Bauausführungen der Neuzeit. Berlin, 1882.

J. M. v. Mauch: Die architektonischen Ordnungen der Griechen und Römer, und der neueren Meister. Berlin, 1862.

A Magyar Mérnök- és Épitészegylet Közlönye. Szerk.: Ambrozovics Béla, Ney Béla, Schwarczel Sándor. Budapest, 1870-85.

Wiener Monumental-Bauten. Hof-Opernhaus von van der Nüll und Siccardsburg, Justizpalast von A. Wielemans. Wien.

Myskovszky Viktor: Magyarország középkori és rennaissance-stilü müemlékei. Bécs, 1885.

Félex Narjaux: Palais, monuments élevés par laville 1850-1880. Paris, 1883.

Publicationen des Vereines ,Wiener Bauhütte”.

M. M. Wulliam, Farge: Le recueil d'architecture choix de documents pratiques. Architecture religieuse, architecture civile, architecture communale, architecture militaire, art funéraire, construction privées: urbanies et suburbanies, construction rurales et industrielles, décoration, ameublement, etc., etc. Paris, 1878-85.

Deutsche Renaissance. Eine Sammlung von Gegenständen der Architektur. Decoration und Kunstgewerbe in Original-Aufnahmen. Szerk.: A. Scheffers. Leipzig, 1881-85.

Revue generale de l'architecture et des travaux publics. Journal d'architectes. szerk.: M. César Daly. Paris, 1880-85.

F. Schwenke: Ausgeführte Möbel- und Zimmereinrichtungen der Gegenwart. Berlin, 1881-84.

Société anonyme des hauts-fourneaux et fonderies du Val D'Osne. Fontes d'art. Paris.

A Wéber Antal életrajzát és építészetét feltáró kutatást az NKA Nemzeti Kulturális Alap támogatta. 


\section{THE LIBRARY OF ANTAL WÉBER \\ ADDITIVE TO THE RESEARCH OF THE 19TH CENTURY HUNGARIAN ARCHITECTURAL PROFESSIONAL-LITERATURE}

\section{Summary}

In the 19th century the number of the published architectural books had been risen. With the advance of the different engraving and litograph technologies the printing became much cheaper. From the middle of the century more external publishers were dealing with publishing architectural professional literature. In comprising with the first half of the century, the Hungarian architecturalperiodicals gave the architects information faster about the tenders, the gone up buildings and contemporary art. The tematical analysis of the library of Antal Wéber - a 19th century architect can give us more particular picture about the situation of architectural professional-literature in Hungary. The article gives the whole list of the books and the periodicals in Antal Wéber's library, too.

Keywords: architecture-history, historism, architectural professional literature 